\title{
Ovarian Large Cell Neuroendocrine Carcinoma
}

National Cancer Institute

\section{Source}

National Cancer Institute. Ovarian Large Cell Neuroendocrine Carcinoma. NCI Thesaurus. Code $C 5238$

A carcinoma that arises from the ovary and is characterized by the presence of large malignant cells exhibiting neuroendocrine differentiation. The prognosis is poor. 